\title{
Performance Evaluation of Freeze Crystallization for removal of Water and Sodium Sulfate from Mine Wastewater
}

\author{
P.M Ramothole, J.P Maree, M.S Onyango and A Adeniyi
}

\begin{abstract}
Mine water treatment aims for zero waste generation. Freeze crystallization was evaluated for treatment of reverse osmosis brine rich in sodium sulfate. The aim was to recover potable water and $\mathrm{Na}_{2} \mathrm{SO}_{4} \cdot 10 \mathrm{H}_{2} \mathrm{O}$. A chiller was used to cool the brine to freezing temperature. Only ice was produced while $\mathrm{Na}_{2} \mathrm{SO}_{4}$ was below its saturation level, about $45 \mathrm{~g} / \mathrm{L}$ ( as $\mathrm{Na}_{2} \mathrm{SO}_{4}$ ). With further ice removal, $\mathrm{Na}_{2} \mathrm{SO}_{4} \cdot 10 \mathrm{H}_{2} \mathrm{O}$ started to crystallize. As water recovery increased from 0 to $80 \%$, it was noticed that: (i) The freezing point decreased from $-2^{\circ} \mathrm{C}$ at the start of ice formation, to $-4{ }^{\circ} \mathrm{C}$ when $\mathrm{Na}_{2} \mathrm{SO}_{4} \cdot 10 \mathrm{H}_{2} \mathrm{O}$ started to crystallize, (ii) ice purity was determined by measuring TDS, which increased from $2000 \mathrm{mg} / \mathrm{L}$ to $3000 \mathrm{mg} / \mathrm{L}$ and (iii) Energy utilization amounted to $10 \mathrm{kWh} / \mathrm{m}^{3}$ during cooling to the freezing point and to $100 \mathrm{kWh} / \mathrm{m}^{3}$ when ice and $\mathrm{Na}_{2} \mathrm{SO}_{4} \cdot 10 \mathrm{H}_{2} \mathrm{O}$ were formed.
\end{abstract}

Keywords - Freeze desalination, Mine water, Sodium sulfate, Ice purity, Energy utilization

\section{INTRODUCTION}

Currently industrial brines and mine water are managed by prioritizing their disposal rather than treatment. Brines produced from mining, during metal processing, and other industrial activities in South Africa are mainly stored in lined ponds. Those ponds lose water through evaporation during the warm, dry season. During the rainy season there are high risks of spillages as rain water may result in overflowing of the ponds. Serious damage to the environment may result subsequent to these spillages of brine, which is highly saline. As a result, the dependence on natural evaporation, a technique which is popular in South Africa, is not recommended. It is also inadequate in terms of environmental safety and human health. Nano filtration and reverse osmosis (RO) have also been employed for desalination of mine water producing clean water and brine. Owing to new requirements for zero waste disposal, continuation of research is necessary to overcome shortcomings related to current methods of brine treatment [1]. This research may lead to new alternative methods and/or technologies for brine treatment.

Manuscript received October 20, 2020. This work was supported in part by the S.A Department of Trade, Industry and Compensation (dtic)

Department of Chemical, Metallurgical and Materials Engineering, Faculty of Engineering and the Built Environment, Tshwane University of Technology, Private Bag X680, Pretoria, 0001, South Africa.

Department of Water and Sanitation, University of Limpopo, University Street, Polokwane, Limpopo, South Africa.

ROC Water Technologies, P O Box 70075, Die Wilgers, Pretoria, South Africa
Several methods such as RO, Electrodialysis and Freeze Desalination (FD) are some of the technologies being utilized for treatment of highly saline mine water. RO is widely used for desalination of both seawater and mine water. Although RO can recover up to $90 \%$ potable water, one of its major disadvantages include membrane fouling/scaling which reduces the efficiency [2]. These limitations result in generation of sludge and brine which is mainly disposed of in evaporation ponds and sludge being disposed of at a high cost. This reiterates the need for treatment of brine being stored in ponds to meet zero waste disposal requirements. Freeze Desalination (FD) is the technology that is energy efficient, cost effective and environmentally friendly. Other advantages include, not being vulnerable to corrosion and fouling [3]. It can be implemented in the treatment of the brine generated from RO in particular for mine related water streams. It will further recover more potable water from $\mathrm{RO}$ brine in the form of ice and simultaneously crystallize out the salt in the form of $\mathrm{Na}_{2} \mathrm{SO}_{4}$ which can be sold [4].

The ROC (Reverse Osmosis/Cooling) process was developed for the treatment of brines from desalination processes, such as RO. The objective was to increase recovery of water by up to $99 \%$ and also recover salts such as sodium sulfate in the process. In so doing the generation of both sludge and brine were reduced. In the ROC process, brine is treated with sodium carbonate and sodium hydroxide in the pre-treatment stage to allow selective precipitation of metals $\left(\mathrm{CaCO}_{3}, \mathrm{MnO}_{2}\right.$ and $\left.\mathrm{Mg}(\mathrm{OH})_{2}\right)$. After pre-treatment, the sodium rich water is passed through a membrane stage to produce drinking water and brine. The brine has a concentration high enough to allow $\mathrm{Na}_{2} \mathrm{SO}_{4}$ crystallization upon cooling.

Overall, combining the three stages, sodium alkali pre-treatment, Reverse Osmosis desalination and Cooling crystallization, yields the following improvements to current technologies: (i) reduced RO membrane scaling - long membrane life, (ii) increased water recovery - no brine generation, (iii) elimination of mixed sludge generation - no sludge disposal costs, and (iv) production of saleable products from polluted water [5]. This study will focus on the recovery of reusable water and/or commercial salt $\left(\mathrm{Na}_{2} \mathrm{SO}_{4} \cdot 10 \mathrm{H}_{2} \mathrm{O}\right)$ from mine waste water and by so doing it will seek to improve the quality of recovered water and lower the amount of generated waste. 


\section{A. Crystallisation}

The crystallization of sodium sulfate hydrates is an exothermic process. This means that crystallization and dissolution of hydrates could be monitored through temperature measurement of a saturated solution undergoing cooling/heating cycles [6]. Crystallisation is a phase change in which a component is recovered from a solution, melt or vapour phase in crystalline form. It is a process which is dependent upon the thermodynamic driving force for nucleation and crystal growth [7].

\section{B. Product quality}

Crystal size distribution generally indicates quality of the product forming crystallisation process. The larger the crystals the higher the quality of the product. In ice formation, larger crystal size results in a more rapid filtration rate and purer ice crystal recovery. Recirculation enhances crystal growth by allowing crystal lattices to increase in size resulting in larger crystals [7].

\section{Eutectic freeze crystallisation}

The concept of freezing a solution in order to separate water and solutes is not a new one. Many authors have described such a method as a means of separation. Eutectic Freeze Crystallization (EFC) uses these concepts and focuses on a specific area of freeze crystallization, namely, operating at the eutectic point of two components (ice and salt). Different salt-water systems have different eutectic compositions and temperatures. The eutectic point of a solution is defined as the composition of a solution that has the lowest crystallisation temperature of any other composition of the same solution or simply as the composition and temperature below which both solvent and solute crystallise out of solution [7]. The principle of the EFC concept can be described using a typical phase diagram of a binary aqueous solution, shown in Figure 1. The concentration of dissolved solids in waste waters is usually very low, a few grams per litre, thus ice will generally crystallize first. The phase diagram used to describe the EFC process therefore has the starting position on the left side (Fig. 1) of the eutectic point because this is the region where ice crystallizes first [1].

\section{Freeze desalination}

Freeze desalination is an alternative method, based on salt rejection from water during freezing. Salt rejection in freeze desalination is due to the small dimensions of the ice crystal lattice that excludes the salt ions during partial freezing instead of being incorporated in the crystal lattice of the ice. The rejection of salt ions out of the solid phase (ice) is highly related to the hydration free energy and hydrated or ionic radius of the salt ions. Hydration free energy is the energy which indicates the stability of the hydrated ions compared to their unhydrated counterparts. Ions with smaller energy of hydration have less association with water, and hence are more likely to be rejected from the ice phase [3]. Freeze desalination is a natural phenomenon based on that ice crystals are essentially made up of pure water, and have the properties of pure water. Salt ions exert a freezing point depression effect as shown by molecular simulations [3].

\section{MATERIALS AND METHODS}

\section{A. Feedstock}

A30 g/L Na $\mathrm{SO}_{4}$ solution was used as feed.

\section{B. Equipment}

Chiller, cooling reactor, clarifier and ice separator at the Brine Treatment Plant, based at A-Thermal Retort Technologies (Olifantsfontein) was used for the cooling process to recover water and $\mathrm{Na}_{2} \mathrm{SO}_{4}$ via ice formation.

\section{Software}

OLI Software was used to predict the aqueous behavior of various compounds in solution [8].

\section{Procedure}

The following approach was followed:

A $15 \mathrm{~kW}$ Chiller was utilized to cool a secondary refrigerant (water/ methanol mixture) to between $-4^{\circ} \mathrm{C}$ and $-8^{\circ} \mathrm{C}$. Cooling down of brine, rich in sodium sulfate, to temperatures between $-3^{\circ} \mathrm{C}$ and $-5^{\circ} \mathrm{C}$ was achieved by passing it through a heat exchanger and further cooling down of the brine to between $-4^{\circ} \mathrm{C}$ and $-6^{\circ} \mathrm{C}$ for ice formation to recover clean water. The slurry from the heat exchanger was pumped into the clarifier to allow separation through settling as the salt crystals that have formed have higher density. For ice formation, the ice slurry was pumped directly to the ice separator where the ice was trapped on a net.

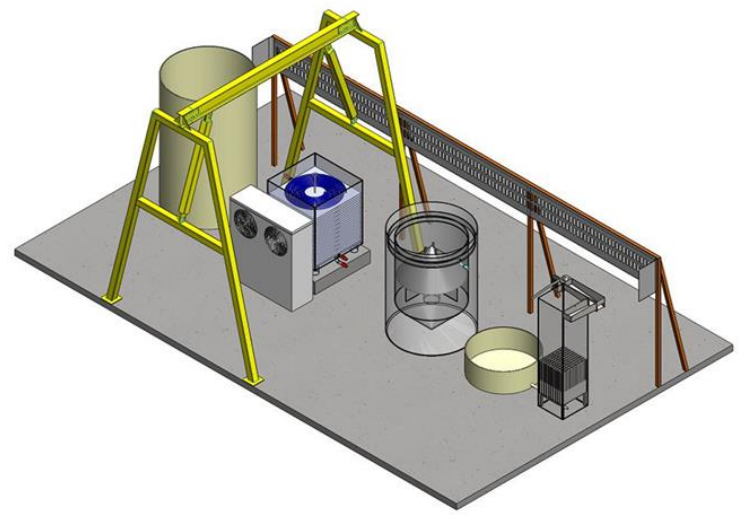

Fig. 1: Schematic diagram of the Freeze Crystallization unit $(15 \mathrm{~kW}$ Chiller, Heat exchanger for TDS cooling and ice separation, Clarifier for salt/liquid/ice separation

\section{RESULTS AND DISCUSSION}

\section{A. Water quality}

The feed water had a TDS of $12540 \mathrm{mg} / \mathrm{L}$. The TDS values of the ice samples were less than $3900 \mathrm{mg} / \mathrm{L}$ and became lower over time. The sample collected after $\mathrm{x}$ min had a TDS of 3868 $\mathrm{mg} / \mathrm{L}$ and after y min' $2989 \mathrm{mg} / \mathrm{L}$. The raised TDS concentration was ascribed to larger ice crystals being formed over time. If this TDS concentration is too high for reuse of the water it can be retreated in the RO plant. The brine concentration increased with time from 13430 to $14070 \mathrm{mg} / \mathrm{L}$. 
The brine increased slightly in concentration, but also contained some precipitate. OLI Software showed that the precipitate that formed was $\mathrm{Na}_{2} \mathrm{SO}_{4} \cdot 10 \mathrm{H}_{2} \mathrm{O}$. As water recovery increased from $7.2 \%$ in Sample 1 to $57.3 \%$ in Sample 3, the saturation level of $\mathrm{Na}_{2} \mathrm{SO}_{4}$ was exceeded, resulting in the crystallization of $\mathrm{Na}_{2} \mathrm{SO}_{4} \cdot 10 \mathrm{H}_{2} \mathrm{O}$ (Table 2). It was noted that: (i) $\mathrm{Na}_{2} \mathrm{SO}_{4}$ remained in solution up to its solubility level of $44310 \mathrm{mg} / \mathrm{L} \mathrm{Na}_{2} \mathrm{SO}_{4}$, (ii) the enthalpy increased from - 3886864 to $-836444 \mathrm{Cal} / \mathrm{kg}$ when $80 \%$ water was removed through ice formation. For water with zero $\mathrm{Na}_{2} \mathrm{SO}_{4}$ content, the enthalpy drop was from $-3816720 \mathrm{Cal} / \mathrm{kg}$ to $-763343 \mathrm{Cal} / \mathrm{kg}$. This showed that the additional energy needed owing to the exothermic energy released from $\mathrm{Na}_{2} \mathrm{SO}_{4} \cdot 10 \mathrm{H}_{2} \mathrm{O}$ was insignificant compared to what was needed for ice formation.

\section{B. Energy utilization}

Table 3 shows the theoretical energy needed for cooling $1 \mathrm{t} / \mathrm{h}$ of water from $25^{\circ} \mathrm{C}$ to $-2^{\circ} \mathrm{C}$ and for freezing $1 \mathrm{t} / \mathrm{h}$. For cooling, with a COP of 3, Energy utilization amounts to $10.45 \mathrm{kWh} / \mathrm{t}$ water and for freezing to $91.7 \mathrm{kWh} / \mathrm{t}$ ice. Table 4 shows the actual energy utilization when energy utilization was calculated in two ways: (i) Using the mass of water or ice cooled, time period and temperature drop in the case of cooling, and (ii) $\mathrm{kWh}$ measurements, time and mass of water cooled or mass of ice formed. For cooling, the COP value was calculated to be 2.05 (average of 4.77 and 1.37). For Freezing the COP value was calculated to be 0.46 (average of 0.48 and 0.44 ). It is expected that with more results and longer operation periods the COP for cooling will stabilize at 3 and for freezing at 1.

\section{Feasibility}

The total costs of waste transportation and disposal amounts to R2 350/ $\mathrm{m}^{3}$ (Table 5). With Freeze Crystallization, these costs can be reduced down to $\mathrm{R} 112.72 / \mathrm{m}^{3}$ (Table 6). These costs can be reduced significantly if the salt is processed to saleable form. $\mathrm{Na}_{2} \mathrm{SO}_{4} \cdot 10 \mathrm{H}_{2} \mathrm{O}$, for example, can be processed to $\mathrm{Na}_{2} \mathrm{CO}_{3}$ where $\mathrm{Na}_{2} \mathrm{SO}_{4}$ has a selling price of $\mathrm{R} 700 / \mathrm{t}$, and $\mathrm{Na}_{2} \mathrm{CO}_{3}$ a selling price of $\mathrm{R} 5000 / \mathrm{t}$.

\section{CONCLUSION}

It is recommended that Freeze Crystallization be used for treatment of leachate from mine dumps, solid waste disposal sites and brine streams from industrial and seawater desalination plants with the aim to recover saleable products such as water, $\mathrm{Fe}(\mathrm{OH})_{3}, \mathrm{Al}(\mathrm{OH})_{3}, \mathrm{Al}_{2}\left(\mathrm{SO}_{4}\right)_{3}, \mathrm{CaSO}_{4} \mathrm{Na}_{2} \mathrm{SO}_{4}$ and $\mathrm{MgSO}_{4}$.

\section{ACKNOWLEDGMENT}

The authors express their gratitude to A Thermal Retort Technologies for making the freeze crystallization plant available and the South African Water Research Commission for financial support through its Wader Programme. Dr Fritz Carlsson is thanked for proof-reading and editorial input.

\section{REFERENCES}

[1] D. G. Randall, J. Nathoo and A. E. Lewis, "A case study for treating a reverse osmosis brine using Eutectic Freeze Crystallization"Approaching a zero waste process," Desalination, vol. 266, pp. 256-262, 2011. https://doi.org/10.1016/j.desal.2010.08.034

[2] S. T. Reddy, A. E. Lewis, G. J. Witkamp, H. J. M. Kramer and J. van Spronsen, "Recovery of Na2SO4-10H2O from reverse osmosis retentate by eutectic freeze crystallization technology," Chemical Engineering Research and Design, vol. 88, pp. 1153-1157, 2010. https://doi.org/10.1016/j.cherd.2010.01.010

[3] F. Melak, A. Ambelu, H. Astatkie, G. du Laing and E. Alemayehu, "Freeze desalination as point-of-use water defluoridation technique," Applied Water Science, vol. 9, p. 34, 2019. https://doi.org/10.1007/s13201-019-0913-0

[4] P. Bhide and A. Shaligram, "Freeze desalination process-an overview," vol. 4, pp. 716-719, 2016.

[5] T. Mtombeni, J. P. Maree, C. M. Zvinowanda, O. Asante and W. Louw, "Improved freeze desalination process for recovery of water and salts from brines.," Mbombela, 2014.

[6] M. F. C. Denecker, R. L. Hebert, J. Wassermann, G. Dosseh, B. Menendez and A. Bourges, "Experimental study of crystallisation of sodium sulfate hydrates through temperature monitoring," Environmental Earth Science, vol. 72, pp. 5089-5099, 2014. https://doi.org/10.1007/s12665-014-3379-2

[7] J. Chivavava, B. Aspeling, D. Jooste, E. Peters, D. Ndoro, H. Heydenrych, M. R. Pascula and A. Lewis, "Continuous eutectic freeze crystallisation," University of Cape Town, Cape Town, 2018.

[8] OLI, "http://www.olisystems.com/.," 2311 2015. [Online]. [Accessed 2015].

[9] T. Mtombeni, J. P. Maree and N. Zikalala, "Desalination with combined membrane filtration/freeze desalination process," Durban, 2016. 
TABLE I. WATER QUALITY OF FEED, BRINE AND MELTED ICE SAMPLES WITH INCREASED WATER RECOVERY - ACTUAL RESULTS

\begin{tabular}{|l|l|r|r|r|r|r|r|r|}
\hline Parameter & \multicolumn{1}{|c|}{ Unit } & \multicolumn{1}{|c|}{ Feed } & \multicolumn{3}{|c|}{ Brine } & \multicolumn{3}{|c|}{ Ice } \\
\hline Water recovery & & & Sample 1 & Sample 2 & Sample 3 & Sample 1 & Sample 2 & Sample 3 \\
\hline Solution & & 0.0 & 20.0 & 80.0 & 0.0 & 20.0 & 80.0 \\
\hline $\mathrm{pH}$ & & & & & & & & \\
\hline $\mathrm{TDS}$ & & 9.3 & 8.9 & 8.8 & 8.8 & 9.0 & 9.0 & 9.1 \\
\hline EC & $\mathrm{mg} / \mathrm{L}$ & 12540.0 & 13430.0 & 13550.0 & 14070.0 & 3868.0 & 3480.0 & 2989.0 \\
\hline Volume & $\mathrm{mS} / \mathrm{cm}$ & 22.1 & 23.2 & 23.6 & 26.0 & 7.8 & 6.8 & 6.0 \\
\hline Ice & $\mathrm{L}$ & 200.0 & 185.5 & 141.6 & 85.3 & & & \\
\hline Ice recovery & $\mathrm{kg}$ & & 14.5 & 58.4 & 114.7 & & & \\
\hline
\end{tabular}

TABLE II. OLI PREDICTED VALUES OF VARIOUS PARAMETERS DURING WATER REMOVAL THOUGH ICE CRYSTALLIZATION

\begin{tabular}{|c|c|c|c|c|c|c|c|c|c|c|c|c|}
\hline 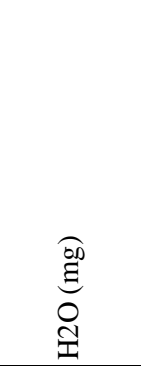 & 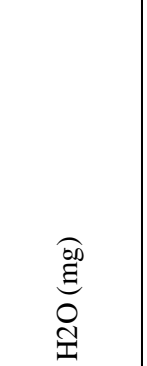 & 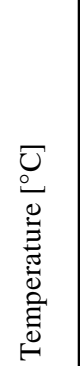 & II & 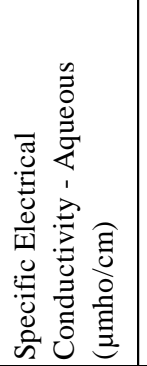 & 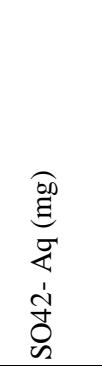 & 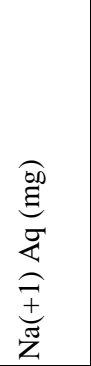 & 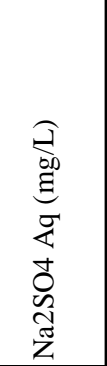 & 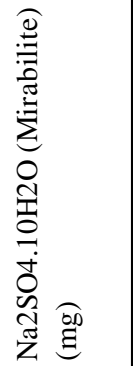 & 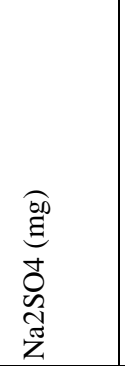 & 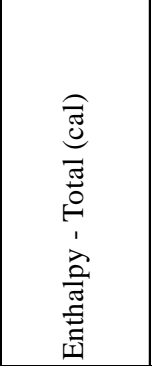 & 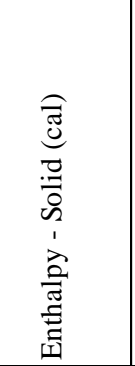 & 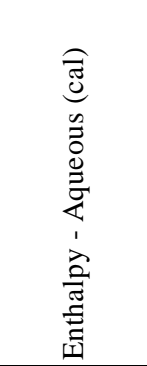 \\
\hline 1000000 & 1000000 & 0 & 8 & 12592 & 20317 & 9711 & 30028 & 0 & 30000 & -3886864 & & -3886864 \\
\hline 920000 & 920000 & 0 & 8 & 13389 & 20317 & 9711 & 32640 & 0 & 30000 & -3581530 & & -3581530 \\
\hline 840000 & 840000 & 0 & 8 & 14311 & 20317 & 9711 & 35748 & 0 & 30000 & -3276196 & & -3276196 \\
\hline 760000 & 760000 & 0 & 8 & 15391 & 20317 & 9711 & 39511 & 0 & 30000 & -2970863 & & -2970863 \\
\hline 680000 & 680000 & 0 & 8 & 16676 & 20317 & 9711 & 44159 & 0 & 30000 & -2665530 & & -2665530 \\
\hline 360000 & 341102 & 0 & 8 & 16717 & 10226 & 4888 & 44310 & 33798 & 30000 & -1446135 & -108930 & -1337205 \\
\hline 280000 & 256343 & 0 & 8 & 16717 & 7685 & 3673 & 44310 & 42309 & 30000 & -1141289 & -136360 & -1004930 \\
\hline 200000 & 171585 & 0 & 8 & 16717 & 5144 & 2459 & 44310 & 50820 & 30000 & -836444 & -163790 & -672654 \\
\hline
\end{tabular}

TABLE III THEORETICAL ENERGY CONSUMPTION FOR COOLING WATER AND FOR FREEZING (80\%)

\begin{tabular}{|l|c|c|c|c|c|}
\hline Parameter & Symbol & Unit & Cooling & Ice & Total \\
\hline Water flow & $\mathrm{q}$ & $\mathrm{t} / \mathrm{h}$ & 1.00 & 1.00 & \\
\hline Water flow & $\mathrm{q}$ & $\mathrm{kg} / \mathrm{sec}$ & 0.28 & 0.28 & 0.28 \\
\hline Heat coef & $\mathrm{Cp}$ & $\mathrm{kJ} /\left(\mathrm{kg} .{ }^{\circ} \mathrm{K}\right)$ & 4.18 & 330 & \\
\hline Temp dif & $\mathrm{dT}$ & $\mathrm{K}$ & 25 & -2 & \\
\hline M.Cp.dT/t & $\mathrm{E}$ & $\mathrm{kJ} / \mathrm{sec}$ & 31.35 & 91.67 & 123.02 \\
\hline Power & $\mathrm{P}$ & $\mathrm{kW}$ & 31.35 & 91.67 & 123.02 \\
\hline Flow & $\mathrm{q}$ & $\mathrm{m}^{3} / \mathrm{h}$ & 1.00 & 1.00 & 1.00 \\
\hline E consump & & $\mathrm{kWh} / \mathrm{t}$ & 31.35 & 91.67 & 123.02 \\
\hline COP & & & 3.00 & 1.00 & 1.00 \\
\hline E consump & & $\mathrm{kWh} / \mathrm{t}$ & 10.45 & 91.67 & 123.02 \\
\hline Cost & & $\mathrm{R} / \mathrm{kWh}$ & 1.00 & 1.00 & 1.00 \\
\hline Cost & & $\mathrm{R} / \mathrm{t}$ & 10.45 & 91.67 & 123.02 \\
\hline
\end{tabular}


TABLE IV. TEMPORAL BEHAVIOR OF VARIOUS PARAMETERS DURING ICE AND SALT PRODUCTION WITH FREEZE CRYSTALLIZATION

\begin{tabular}{|c|c|c|c|c|c|c|c|c|c|c|c|c|c|c|}
\hline Time & d Time & Volume & Temp & Ice & Acc Ice & $\begin{array}{l}\text { Energy } \\
\text { utilised }\end{array}$ & Power & \begin{tabular}{|l} 
Energy \\
utilized Calc \\
1
\end{tabular} & $\begin{array}{l}\text { Energy } \\
\text { utilized Calc } \\
2\end{array}$ & \begin{tabular}{|l|} 
Energy \\
utilized $_{\text {theo }}$ \\
$\mathrm{r}_{\mathrm{r}} \mathrm{COP}=1$
\end{tabular} & COP1 & COP2 & $\begin{array}{l}\text { Energy } \\
\text { measured }\end{array}$ & $\begin{array}{l}\text { Energy } \\
\text { reading }\end{array}$ \\
\hline \multicolumn{15}{|l|}{\begin{tabular}{|l} 
Cooling \\
\end{tabular}} \\
\hline $\mathrm{h}$ & $\mathrm{h}$ & $\mathrm{L}$ & ${ }^{\circ} \mathrm{C}$ & $\mathrm{kg}$ & & $\mathrm{kJ}$ & $\mathrm{kW}$ & $\mathrm{kWh} / \mathrm{t}$ & $\begin{array}{c}\mathrm{kWh} / \text { Time/ } \\
\mathrm{t}_{\text {water }}\end{array}$ & & & & $\mathrm{kWh}$ & $\mathrm{kWh}$ \\
\hline 1.0 & & 126.00 & 2 & & 0 & 9480.2 & 2.63 & 9.48 & 28.4 & 31.4 & 3.31 & 1.10 & 3.58 & 19694.0 \\
\hline 1.5 & & 126.00 & 1 & & 0 & 10006.9 & 1.85 & 6.67 & 37.0 & 31.4 & 4.70 & 0.85 & 4.66 & 19695.1 \\
\hline 2.0 & & 126.00 & 0 & & 0 & 10533.6 & 1.46 & 5.27 & 46.7 & 31.4 & 5.95 & 0.67 & 5.88 & 19696.3 \\
\hline 0.0 & & 126.00 & 8 & & 0 & 0.0 & 0.00 & - & & & & & 0.00 & 19713.0 \\
\hline 0.5 & & 126.00 & 2 & & 0 & 3160.1 & 1.76 & 6.32 & 13.8 & 31.4 & 4.96 & 2.27 & 1.74 & 19714.7 \\
\hline 1.0 & & 126.00 & 0 & & 0 & 4213.4 & 1.17 & 4.21 & 22.5 & 31.4 & 7.44 & 1.39 & 2.84 & 19715.8 \\
\hline \begin{tabular}{|l|} 
Average \\
\end{tabular} & & & & & & & & & & & 4.77 & 1.37 & & \\
\hline 3.5 & 2.0 & 126.00 & 1 & 14.46 & 14.5 & 4771.8 & 0.66 & 165.00 & & & & & 2.89 & 19699.2 \\
\hline 6.0 & 2.5 & 126.00 & 4 & 16.21 & 30.71 & 5349.3 & 0.59 & 132.00 & 301.0 & \begin{tabular}{|l|}
91.7 \\
\end{tabular} & 0.69 & 0.30 & 7.77 & 19704.1 \\
\hline 9.0 & 3.0 & 126.00 & -1 & 18.98 & 49.69 & 6263.4 & 0.58 & 110.0 & 354.6 & 91.7 & 0.83 & 0.26 & 14.50 & 19718.8 \\
\hline 10.0 & 1.0 & 126.00 & \begin{tabular}{|l|}
-1 \\
\end{tabular} & 8.74 & 58.43 & 2884.2 & 0.80 & 330.0 & 204.8 & 91.7 & 0.28 & 0.45 & 16.29 & 19720.6 \\
\hline 12.0 & 2.0 & 126.00 & 0 & 14.05 & 72.48 & 4636.5 & 0.64 & 165.0 & 264.8 & 91.7 & 0.56 & 0.35 & 20.01 & 19724.3 \\
\hline 13.0 & 1.0 & 126.00 & 0 & 13.19 & 85.67 & 4352.7 & 1.21 & 330.0 & 124.3 & 91.7 & 0.28 & 0.74 & 21.65 & 19726.0 \\
\hline 14.0 & 1.0 & 126.00 & 0 & 13.8 & 99.47 & 4554.0 & 1.27 & 330.0 & 211.6 & 91.7 & 0.28 & 0.43 & 24.57 & 19728.9 \\
\hline 15.5 & 1.5 & 126.00 & 0 & 15.25 & 114.72 & 5032.5 & 0.93 & 220.0 & 164.6 & 91.7 & 0.42 & 0.56 & 27.08 & 19731.4 \\
\hline Average & & & & & & & & & & & 0.48 & 0.44 & & \\
\hline
\end{tabular}

Note 1 - Energy utilized Calc 1 - Caculated from mass ice produced and time period

Note 2 - Energy utilized Calc 2 - Calculated from $\mathrm{kWh}$ reading

TABLE V. DisPosal COST OF WASTE

\begin{tabular}{|l|c|c|c|}
\hline Cost item & Unit & $\mathbf{R} / \mathbf{t}$ & $\mathbf{R} / \mathbf{m}^{\mathbf{3}}$ \\
\hline Waste disposal cost & $\mathrm{R} / \mathrm{t}$ & 1000 & 1000 \\
\hline Waste transport cost & $\mathrm{R} / \mathrm{t}$ & 1500 & 1350 \\
\hline Total & & & 2350 \\
\hline
\end{tabular}

TABLE VI. FEASIBILITY OF THE FREEZE CRYSTALLIZATION PROCESS

\begin{tabular}{|l|c|r|r|r|}
\hline \multicolumn{1}{|c|}{ Cost item } & \multicolumn{1}{c|}{ Unit } & \multicolumn{1}{c|}{ Cooling } & \multicolumn{1}{c|}{ Freezing } & \multicolumn{1}{c|}{ Capital cost } \\
\hline Capacity & $\mathrm{t} / \mathrm{h}$ & 0.30 & 0.24 & 0.30 \\
\hline Electricity & $\mathrm{kW} / \mathrm{m}^{3}$ & 10.45 & 91.67 & 102.12 \\
\hline Electricity cost & $\mathrm{R} / \mathrm{kWh}$ & 1.00 & 1.00 & \\
\hline Capital cost & $\mathrm{R}$ & & & 1090800 \\
\hline Capital cost & $\mathrm{R} / \mathrm{ML} / \mathrm{d}$ & & & 51171221 \\
\hline Capital redemption cost (120 months; 8\% interest/a) & $\mathrm{R} / \mathrm{m}^{3}$ & & & 20.41 \\
\hline Flow & $\mathrm{R} / \mathrm{m}^{3}$ & 1.00 & 0.80 & \\
\hline Electricity cost & $\mathrm{R} / \mathrm{m}^{3}$ & 10.45 & 73.34 & 83.79 \\
\hline Labour (6 x R8000/person/month) & $\mathrm{R} / \mathrm{m}^{3}$ & & & 3.16 \\
\hline Management, Admin and Insurance (5\%) & $\mathrm{R} / \mathrm{m}^{3}$ & & & \\
\hline Total & $\mathrm{R} / \mathrm{m}^{3}$ & & & \\
\hline
\end{tabular}

